Peter Ghavami

Big Data Management 



\section{Peter Ghavami}

Big Data

Management

Data Governance Principles for Big Data Analytics

\section{DE GRUYTER}


The author and publisher have taken care in preparations of this book, but make no expressed or implied warranty of any kind and assume no responsibility for errors or omissions. No liability is assumed for the incidental or consequential damages in connection with or arising out of the use of the information or designs contained herein.

ISBN 978-3-11-066291-7

e-ISBN (PDF) 978-3-11-066406-5

e-ISBN (EPUB) 978-3-11-066432-4

Library of Congress Control Number: 2020943612

Bibliographic information published by the Deutsche Nationalbibliothek The Deutsche Nationalbibliothek lists this publication in the Deutsche Nationalbibliografie; detailed bibliographic data are available on the Internet at http://dnb.dnb.de.

(c) 2021 Walter de Gruyter GmbH, Berlin/Boston Cover image: DKosig/iStock/Getty Images Plus Typesetting: Integra Software Services Pvt. Ltd. Printing and binding: $\mathrm{CPI}$ books $\mathrm{GmbH}$, Leck

www.degruyter.com 
To my beautiful wife Massi,

whose unwavering love and support make these accomplishments possible and worth pursuing. 
